\title{
Isolation and Identification of Bacteria Associated with Pre and Post Processing of Groundnut Cake in Sokoto State, North-Western Nigeria
}

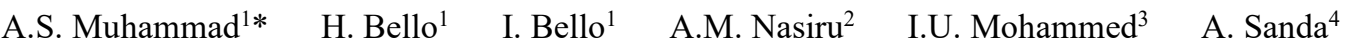 \\ S.A. Anka ${ }^{4} \quad$ A.B. Rabah ${ }^{5} \quad$ Y. Garba ${ }^{6} \quad$ T.S. Bello ${ }^{7}$ \\ 1.Department of Crop Science, Usmanu Danfodiyo University Sokoto \\ 2.Department of Forestry and Environment, Usmanu Danfodiyo University Sokoto \\ 3.Department of Crop Science, Kebbi State University of Science and Technology Aliero \\ 4.Department of Biological Sciences, Usmanu Danfodiyo University Sokoto \\ 5.Department of Microbiology, Usmanu Danfodiyo University, Sokoto \\ 6.Department of Crop Production, Ibrahim Badamasi Babangida University, Lapai, Niger State \\ 7.Department of Biology, Nigerian Army University, Biu, Borno State
}

\begin{abstract}
This study was conducted to assess the bacterial contamination between the groundnut cakes and paste obtained from Rural areas (Bodinga, kware) and that obtained within the metropolis at Urban areas (Arkilla and 'Yargoriba) of Sokoto metropolis. A total of 8 samples of ready to eat groundnut cake and pastes were purchased, 4 of which were cake packaged in polythene and 4 paste packaged in plastic rubbers. The samples were analyzed microbiologically using standard procedures. Bacteria species associated with the samples collected from the rural areas were identified as Bacillus lentus, B. megaterium, B. licheniformis, Listeria monocytogene, Staphylococcus aureus while those associated with samples collected from the urban areas were identified as Bacillus lentus, $B$. megaterium, B. licheniformis, Listeria monocytogene, Staphylococcus aureus and S. hominis. There was higher bacteria count on samples from rural areas compared to those from urban areas. This might be as a result of unhygienic practices during the processing of the product which may range from methods of obtaining and quality of raw materials including sources of water, packaging, handling and distribution of the finished product to the final consumers. Based on these, it is recommended that Producers of groundnut cake should use good hygienic places, raw material and equipment to reduce the risk of microbial contamination.
\end{abstract}

Keywords: Isolation, Identification, Bacteria, Processing, Groundnut

DOI: $10.7176 / \mathrm{JBAH} / 10-12-03$

Publication date:June $30^{\text {th }} 2020$

\section{INTRODUCTION}

Groundnut (Arachis hypogaea L.) cake, popularly called "Kulikuli", is produced by extracting oil from the groundnut kernels (Atanda and Akano, 1990). It is a popular snack in Nigeria that is processed locally which exposes it to microbial contamination, as a result of improper processing associated with handling, water impurities during oil extraction, the use of contaminated equipment, air, packaging materials and storage conditions.

Groundnut paste and cake have been frequently associated with food illness in which the initial contamination is traceable to food handlers. Numerous epidemiological reports and studies have implicated food of ready to eat origin as the major vehicle associated with illness caused by food born pathogen (Sokari, 1991). The microbial quality of groundnut cake primarily depends on the quality of raw materials, production process, processing environment, hygiene of the personnel involved in processing and the storage condition. Since the production of groundnut cake and paste is no more limited to oil mills but to local processors, there is possibility of microbial contamination due to the unhygienic practices during the processing, groundnut cakes and pastes can be contaminated with microorganisms. Hence, Microbial and Aflatoxin contamination is a major concern in food safety as they affect humans, animals and the economic growth of any nation (Hwang et al., 2004). Groundnut cake and paste may be contaminated by bacteria such as Staphylococcus spp, Escherichia coli; an indicator of fecal contamination resulting from water supply. The presence of these contaminating organisms in food consumed by large population is of public health concern (Oko et al., 2015).

Therefore, this study was undertaken to assess the bacterial contamination between the groundnut cakes and paste obtained from rural area and that obtained within the Sokoto metropolis of Sokoto state, Nigeria.

\section{MATERIALS AND METHODS}

Study Area

The study area is within Sokoto State; Bodinga, Kware and within Sokoto metropolis; Arkilla and 'Yargoriba. Sokoto lies on $13^{\circ} 01^{\prime} \mathrm{N}, 1^{\circ} 05^{\prime} \mathrm{E}$; at an altitude of $350 \mathrm{~m}$ above sea level (SERC, 2015). The main occupation of Sokoto inhabitants includes; Farming, Fishing and leather work (MOI, 2008). 
Materials and Reagents

The materials and reagents used in the laboratory for these research work are; Nutrient agar, Ethanol, Nutrient broth, Urea agar base, Triple Sugar Iron (TSI) medium, Gram stain reagents, Streptomycin, Petri dishes, Test tubes, Bend glass rod, Glass slide and Cover slip, Conical flask, Distilled water, Aluminum foil, Syringes, Slant bottles, Wire Lupe, Masking tape, Cotton wool, Face mask and Hand gloves.

Samples Collection

Groundnut cake (kulikuli) both pre and post processed where collected at random from four (4) processing units of Sokoto State; Two from Rural areas (Bodinga and Kware) and two from Urban area, that is within Sokoto metropolis (Arkilla and 'Yargoriba). A sample each, of the groundnut paste and cake was collected from each of the four processing units making a total number of eight samples. The Groundnut cake samples were collected in a polythene bag while the Groundnut paste samples in a plastic rubber.

Sample Preparation

The collected groundnut cake samples were reduced to fine particles in the laboratory through the use of sterile porcelain pestle and mortar.

Media Preparation

All glass wares were washed with detergent solution, thoroughly rinsed in several changes of tap water and then air dried. The glass wares were put into a hot air oven and sterilized at temperature of 121 for 15 minutes then allowed to cool down to at room temperature before usage. All media were prepared according to the manufacturer's instructions (labels).

Preparation of Nutrient agar

$28 \mathrm{~g}$ of nutrient agar (NA) powder was weighed on an electrical weighing balance and transferred into a conical flask containing $1000 \mathrm{ml}$ distilled water. The mouth of the conical flask was plugged with a non-absorbent cotton wool, and then wrapped with aluminum foil. The mixture was swirled and heated to obtain a homogenized solution. The solution was autoclaved at $120^{\circ} \mathrm{C}$ for 15 minute with pressure of $15 \mathrm{psi}$, after which the prepared medium was allowed to cool down to about $45^{\circ} \mathrm{C}$, and then poured into Petri dishes and allowed to solidify.

Serial Dilution

Five (5) test-tubes each containing $9 \mathrm{ml}$ distilled water were used for the dilution; $1 \mathrm{~g}$ of each sample was taken and transferred into the first test tube and allowed to dissolve, then mixed; to the second tube, $1 \mathrm{ml}$ of the content from the first test-tube was aseptically taken using sterile syringe and poured into the second (2) test tube. This procedure was repeated up to the last test tube ( 5 test tubes). Thus, making a dilution factor of $10^{-1}, 10^{-2}, 10^{-3}, 10^{-4}$, and $10^{-5}$ respectively.

Bacterial Plates

Samples collected were inoculated into a prepared petri dish containing Nutrient agar (medium for isolation of bacteria). The inoculated Ager media was incubated in an oven at $37^{\circ} \mathrm{c}$ for 24 hours, after which colony growth was observed.

Identification of the isolated bacteria was carried out by first observing the appearance of the colonies produced which is followed by Gram's staining and subsequent sub-culture onto slant bottles containing nutrient Ager, followed by biochemical test.

Identification and Characterization of the Bacteria Isolates

Identifiable colonies were carefully examined microscopically for characteristics such as the shape, color, size and consistency. Bacteria isolates were characterized based on colony morphology, microscopic appearance and gram staining reactions as well as biochemical tests.

Microscopy

The isolates were identified by picking a colony and placing it on a sterile glass slide, gram stained and viewed under the microscope.

Procedure

Gram staining was conducted by making a smear of the isolates on a glass slide using fixed heat. To the smear on the slides, Crystal violet was poured in drops and allowed for 30seconds then rinsed with water, the films were again covered with Iodine and allowed for another 30seconds then rinsed with water and decolorized with $90 \%$ alcohol. They were again rinsed with water and color stained with safranin for about 20-30 seconds and finally rose with water and dried. Slides were then examined under the oil immersion objective $\left(100^{*}\right)$

Biochemical tests

The pure bacteria isolates were subjected to biochemical characterization. the following biochemical test performed are catalase test, coagulase test, urease test, indole test, citrate utilization test starch hydrolysis and Triple sugar iron(T.S.I) test, which includes hydrogen sulphite, gas, lactose, sucrose, glucose and motility. Lactose fermentation growth at $45^{\circ} \mathrm{C}$ and haemolysis. The tests were performed in accordance with standard procedures described by (Barrow and Feltham 1993).

Catalase Test

This test was used to differentiate those bacteria that produce the enzyme catalase from non-catalase producing 
bacteria.

A drop of $3 \%$ hydrogen peroxide was placed on a glass slide, using a wire loop, the 24-hour colony of each isolate was emulsified into the hydrogen sulphide and observed. A positive test will be indicated by bubbling and frothing. Whereas in a negative test, there will be no bubbling or frothing. (Oyeleke and Manga, 2008)

Indole Test

This is used in determining an organism's ability to produce indole from tryptophan. The organism was grown in tryptophan broth for 24hours, kovacs iodole reagent was then added.

A positive reaction will be indicated by the development of a red color in the reagent layer above the broth within 1 minute.whereas a negative reaction is indicated by yellow color on the medium (Oyeleke and Manga, 2008).

Urease Test

This test is used to detect the ability of an organism to produce the enzyme urease that hydrolysis urea into ammonia and carbon dioxide.

A culture was incubated in urease agar for 48 hours. A positive reaction is indicated by the development of a bright pink or red coloring agar (Beishir, 1991).

Citrate Utilization Test

A Simon citrated agar was used. The development of a deep blue color indicates a positive reaction.

Methyl Red (MR) and Voges Proskaur (VP) Test.

These considered together since they are physiologically related and are incubated into the same medium MR-VP broth and the results obtained are usually opposite (i.e. MR+, VP- or MR-, VP+) (Beishir,1991)

A wire loop full of each isolate was inoculated into glucose phosphate peptone water and then incubated at $37^{\circ} \mathrm{c}$ for 48 hours. Few drops of methyl red were added to the culture (Cheesbrough, 2006).

Vogesproskaur test (VP).

$0.5 \mathrm{ml}$ of $40 \%$ potassium hydroxide was added followed by $1 \mathrm{ml}$ Naphtol. This was shaken vigorously and placed in a sloppy position and was examined for 30-60 minute (Cheesbrough, 2006).

Coagulase Test

Slide Method

Two drops of water were dropped on a clean glass slide. One colony was dropped on each drop of water and emulsified. A flame wire loop was dipped in human plasma and used to stir the bacteria suspension. Visible clumping in 10 seconds shows a positive result.

Starch hydrolysis

Nutrient agar along with starch was prepared and poured into petri dishes. Sub-culture was made from the stock then incubated for 24hours. Iodine was dropped on the sub-cultures and allowed for 1 min then poured out. The organism that appears visible is said to be able to utilize starch while those that appear black are not able to utilize starch.

Triple Sugar Iron (T.S.I)

Inoculum from sub-cultured plates were picked with a sterile straight wire loop and stabbed on the butt and then streak on the surface of slant. The inoculated test tubes were then incubated at $37^{\circ} \mathrm{C}$ for 24 hours.

Since TSI is a composite media, several reactions were read from it after the 24 hours of incubation.

Gas production was determined by the presence of bubbles or cracks on the agar or complete disruption of medium, hydrogen sulphide production can be determined by the blackening of the whole butt or a streak or ring of blackening at the slant butt junction, Motility can be determined by the presence of growth along the area been stabbed by the straight wire loop. If the butt becomes yellow, it is an indication of glucose fermentation, formation of a pink/red color at the slant indicates the presence of lactose and sucrose fermentation (CheeseBrough, 2006).

\section{RESULTS AND DISCUSSION}

Results

Fourteen (14) Bacteria Species were isolated, the frequency of occurrence of these organisms showed that Bacillus megaterium has the highest frequency with $35.7 \%$ followed by Bacillus lentus, Staphylococcus hominis and Listeria monocytogene with $(21.2 \%, 14.3 \%$ and $14.3 \%)$. The least frequency with 7.1 was from Bacillus licheniformis and Staphylococcus aureus (Table 1). 
Table 1: Frequency of occurrence of bacteria isolates associated with groundnut cake and paste obtained from both Rural and Urban area.

\begin{tabular}{lcc}
\hline Species & & Percentage of Occurrence \\
Bacillus lentus & Frequency & 21.2 \\
B. megaterium, & 3 & 35.7 \\
B. licheniformis, & 5 & 7.1 \\
Listeria monocytogene, & 1 & 14.3 \\
Staphylococcus aureus & 2 & 7.1 \\
Staphylococcus hominis & 1 & 14.3 \\
Total & 2 & 100 \\
\hline
\end{tabular}

Colony count of bacteria isolated from groundnut cakes and pastes samples obtained from both Rural and Urban areas of Sokoto State respectively, is presented in Table 2. The results of the average bacteria count observed on the samples collected from Rural areas have shown higher bacteria count compared to those from the urban area.

Table 2: Colony Count of bacteria isolated from groundnut cake and paste samples obtained from both Rural and Urban areas of Sokoto state respectively.

\begin{tabular}{ccccc}
\hline \multicolumn{2}{r}{ Rural area } & Bacteria load $(\mathrm{cfu} / \mathrm{g})$ & Urban area & Bacteria load $(\mathrm{cfu} / \mathrm{g})$ \\
\hline Cake & $\mathrm{A}_{1}$ & $1.84 \times 10^{7}$ & $\mathrm{C}_{1}$ & $1.32 \times 10^{7}$ \\
& $\mathrm{~A}_{2}$ & $1.04 \times 10^{7}$ & $\mathrm{C}_{2}$ & $4.0 \times 10^{6}$ \\
Paste & $\mathrm{B}_{1}$ & $2.20 \times 10^{7}$ & $\mathrm{D}_{1}$ & $8.2 \times 10^{6}$ \\
& $\mathrm{~B}_{2}$ & $1.96 \times 10^{7}$ & $\mathrm{D}_{2}$ & $1.18 \times 10^{7}$ \\
\hline
\end{tabular}

Key: (cfu/g) Colony forming unit/g $\mathrm{A}_{1=}$ Groundnut cake collected from Rural area (Bodinga LGA), $\mathrm{B}_{1}=$ Groundnut cake collected from Rural area (Kware LGA), $\mathrm{C}_{1}=$ Groundnut paste collected from Rural area (Bodinga LGA), $\mathrm{D}_{1}=$ Groundnut paste collected from Rural area (Kware LGA), $\mathrm{A}_{2}=$ Groundnut cake collected from urban area(Arkilla area),$B_{2}=$ Groundnut cake collected from Urban area('Yargoriba area), $C_{2=}$ (Groundnut paste collected from Urban area (Akilla area), $\mathrm{D}_{2}=$ (Groundnut paste collected from Urban area ('Yargoriba area).

The results of biochemical tests on groundnut cake and paste collected from both rural and Urban areas of Sokoto are presented in Table 3 and Table 4. They showed the presence of Bacillus lentus, B. megaterium, B. licheniformis, Listeria monocytogene, Staphylococcus aureus and S. hominis with the exception of Staphylococcus hominis which only appeared on samples collected from the Urban area.

Staphylococcus hominis is a coagulase-negative member of the bacteria genus Staphylococcus, consisting of Gram-positive, spherical cells in clusters. S. hominis is normally found on human skin of usually harmless people, but it can sometimes cause infection in people with abnormally weak immune systems, their presence in food are indication of excessive human handling (Abdalla et al., 2012).

Bacillus lentus, B. megaterium, Listeria monocytogene, Staphylococcus aureus and S. hominis were found to appear on the Groundnut cake samples while Bacillus lentus, B. megaterium, B. licheniformis and Listeria monocytogene, appeared on the Groundnut paste samples.

The presence of Bacillus specie might be due to the fact that it is an abundant spore former in soil, air and water, hence can be present in the food sample as a result of exposure of the product on the road side. This report is in agreement to the studies of (Clarence et al., 2009; Hassan et al., 2014; Okonko et al., 2009; Oluwafemi and Simisaye, 2005). They isolated similar organisms from sausages, meat pie, sea foods and puff, respectively. 
Table 3: Bacteria found on groundnut cake and paste collected from rural areas of 17 Sokoto (Bodinga and Kware) after conducting biochemical test

\begin{tabular}{|c|c|c|c|c|c|c|c|c|c|c|c|c|c|c|c|}
\hline Treatments & GSR & $\mathrm{Ca}$ & $\mathrm{SH}$ & Ur & $\mathrm{Ci}$ & In & MR & VP & Мo & GI & $\mathrm{L}$ & $\mathrm{S}$ & G & $\mathrm{H}_{2} \mathrm{~S}$ & $\begin{array}{l}\text { Possible } \\
\text { organisms }\end{array}$ \\
\hline $\mathrm{A}_{1}$ & $\begin{array}{l}+ \text { ve } \\
\text { Cocci }\end{array}$ & & & & & & & & & & & & & & \\
\hline $\mathrm{A}_{2}$ & $\begin{array}{l}+\mathrm{ve} \\
\text { Cocci }\end{array}$ & + & + & + & + & - & - & - & + & + & + & + & - & - & $\begin{array}{l}\text { Staphylococcus } \\
\text { aureus }\end{array}$ \\
\hline $\mathrm{B}_{1}$ & $\begin{array}{l}+ \text { ve } \\
\text { Rod }\end{array}$ & + & - & - & + & - & - & + & + & + & - & + & - & - & $\begin{array}{l}\text { Listeria } \\
\text { monocytogene }\end{array}$ \\
\hline $\mathrm{B}_{2}$ & $\begin{array}{l}\text { +ve } \\
\text { Rod }\end{array}$ & + & + & + & - & - & + & - & + & + & - & - & - & + & Bacillus lentus \\
\hline $\mathrm{C}_{1}$ & $\begin{array}{l}\text { +ve } \\
\text { Rod }\end{array}$ & + & + & + & - & - & + & - & + & + & - & - & - & + & Bacillus lentus \\
\hline $\mathrm{C}_{2}$ & $\begin{array}{l}\text { +ve } \\
\text { Rod }\end{array}$ & + & + & + & + & - & + & - & + & + & - & + & - & + & $\begin{array}{l}\text { Bacillus } \\
\text { megaterium }\end{array}$ \\
\hline $\mathrm{D}_{1}$ & $\begin{array}{l}\text { +ve } \\
\text { Rod }\end{array}$ & + & + & + & + & - & - & + & + & + & - & - & - & + & $\begin{array}{l}\text { Bacillus } \\
\text { licheniformis }\end{array}$ \\
\hline $\mathrm{D}_{2}$ & $\begin{array}{l}\text { +ve } \\
\text { Rod }\end{array}$ & & & & & & & & & & & & & & \\
\hline
\end{tabular}

Key: $A_{1}$ and $A_{2}$ - Groundnut cake collected from Bodinga LGA, $B_{1}$ and $B_{2}$ - Groundnut cake collected from Kware LGA, $\mathrm{C}_{1}$ and $\mathrm{C}_{2}$ - Groundnut paste collected from Bodinga LGA, $\mathrm{D}_{1}$ and $\mathrm{D}_{2}=$ Groundnut paste collected from Kware LGA. $\mathrm{CA}=$ Catalase test, $\mathrm{SH}=$ Starch hydrolysis, $\mathrm{CI}=$ Citrate, $\mathrm{IN}=$ Indole, $\mathrm{MR}=$ Methyl Red, $\mathrm{VP}=\mathrm{Voges}$ ProskaurMO= Motility, GL= glucose, $\mathrm{LA}=$ Lactose, $\mathrm{SU}=$ Sucrose, $\mathrm{H} 2 \mathrm{~S}=$ Hydogen Sulphite, UR= Urease, Trt= Treatments, GSR= Gram Stain Reaction

Table 4: Bacteria found on samples of groundnut cake and paste obtained within Sokoto metropolis (Urban area) (Arkilla and 'yar goriba) after conducting biochemical test

\begin{tabular}{|c|c|c|c|c|c|c|c|c|c|c|c|c|c|c|c|}
\hline Treatments & GSR & $\mathrm{Ca}$ & $\mathrm{SH}$ & Ur & $\mathrm{Ci}$ & In & MR & VP & Mo & GI & $\mathrm{L}$ & $\mathrm{S}$ & G & $\mathrm{H}_{2} \mathrm{~S}$ & $\begin{array}{l}\text { Possible } \\
\text { organisms }\end{array}$ \\
\hline $\mathrm{A}_{1}$ & $\begin{array}{l}\text { +ve } \\
\text { Rod }\end{array}$ & + & + & + & + & - & + & - & + & + & - & + & - & + & $\begin{array}{l}\text { Bacillus } \\
\text { megaterium }\end{array}$ \\
\hline $\mathrm{A}_{2}$ & $\begin{array}{l}+ \text { ve } \\
\text { Rod }\end{array}$ & + & + & + & + & - & + & - & + & + & - & + & - & + & $\begin{array}{l}\text { Bacillus } \\
\text { megaterium }\end{array}$ \\
\hline $\mathrm{B}_{1}$ & $\begin{array}{l}+\mathrm{ve} \\
\text { Cocci }\end{array}$ & + & + & + & + & - & - & + & - & + & + & + & - & - & $\begin{array}{l}\text { Staphylococcus } \\
\text { hominis }\end{array}$ \\
\hline $\mathrm{B}_{2}$ & $\begin{array}{l}+\mathrm{ve} \\
\text { Cocci }\end{array}$ & + & - & + & + & - & - & + & - & + & + & + & - & - & $\begin{array}{l}\text { Staphylococcus } \\
\text { hominis }\end{array}$ \\
\hline $\mathrm{C}_{1}$ & $\begin{array}{l}+ \text { ve } \\
\text { Rod }\end{array}$ & + & + & + & + & - & + & - & + & + & - & + & - & + & $\begin{array}{l}\text { Bacillus } \\
\text { megaterium }\end{array}$ \\
\hline $\mathrm{C}_{2}$ & $\begin{array}{l}+ \text { ve } \\
\text { Rod }\end{array}$ & + & + & + & - & - & + & - & + & + & - & - & - & + & Bacillus lentus \\
\hline $\mathrm{D}_{1}$ & $\begin{array}{l}\text { +ve } \\
\text { Rod }\end{array}$ & + & - & - & + & - & - & + & + & + & - & - & - & - & $\begin{array}{l}\text { Listeria } \\
\text { monocytogene }\end{array}$ \\
\hline $\mathrm{D}_{2}$ & $\begin{array}{l}+ \text { ve } \\
\text { Rod }\end{array}$ & + & + & + & + & - & + & - & - & + & - & + & - & + & $\begin{array}{l}\text { Bacillus } \\
\text { megaterium }\end{array}$ \\
\hline
\end{tabular}

Key: $\mathrm{A}_{1}$ and $\mathrm{A}_{2}$ - Groundnut cake collected from Arkilla area, $\mathrm{B}_{1}$ and $\mathrm{B}_{2}$ - Groundnut cake collected from 'Yar goriba area, $\mathrm{C}_{1}$ and $\mathrm{C}_{2}$ - Groundnut paste collected from Arkilla area, $\mathrm{D}_{1}$ and $\mathrm{D}_{2}=$ Groundnut paste collected from 'Yar goriba area. $\mathrm{CA}=$ Catalase test, $\mathrm{SH}=\mathrm{Starch}$ hydrolysis, $\mathrm{CI}=$ Citrate, $\mathrm{IN}=$ Indole, $\mathrm{MR}=$ Methyl Red, $\mathrm{VP}=\mathrm{Voges}$ ProskaurMO= Motility, GL= glucose, $\mathrm{LA}=$ Lactose, $\mathrm{SU}=$ Sucrose, H2S= Hydrogen Sulphite, UR= Urease, Trt= Treatments, GSR= Gram Stain Reaction

\section{DISCUSSION}

In this study, a total of eleven (11) organisms were recorded from the microbial analysis on Groundnut cake and paste collected from Urban and rural areas of Sokoto State respectively. Six (6) of which were bacteria and five (5) fungi. The bacteria isolates were identified on the bases of their reactions to biochemical reagents. These organisms include; Bacillus lentus, B. megaterium, B. licheniformis, Listeria monocytogene, Staphylococcus aureus and S. hominis. Morphological characteristics and microscopic examination were used for the identification of fungi isolates. 
This research has revealed a number of bacteria associated with the contamination of groundnut cake and paste which is in agreement with Okwu et al. (2017) who isolated bacteria species of Bacillus spp., Staphylococcus spp., and fungi specie Aspergillus spp. from groundnut in their study. Staphylococcus spp in the groundnut pastes will result if the grinding machine and other utensils are contaminated. According to Doyle (2007), Bacillus spp. and Pseudomonas spp. are normal inhabitants of the soil and are capable of causing disease in humans and animals. These organisms are capable of surviving harsh conditions such as roasting and blending processes. Table 3 shows the statistical analysis using mean and standard error mean (SEM) from the average bacteria count. Groundnut cake from Rural area when compared with Groundnut paste from Rural area showed that between sample A $67.33 \pm 7.58$ and C $35.50 \pm 1.00$ there is significant difference between the mean, and comparing sample B 50.0 \pm 6.25 Groundnut cake from Urban area with D 26.33 \pm 4.79 Groundnut paste from Urban area, there was also a significant difference. Therefore, among the whole samples, sample D is recommended (more acceptable) since it has the least mean \pm SEM value hence, it has less contamination.

\section{CONCLUSION}

The results obtained showed higher bacteria count in samples from Rural areas compared to those from Urban areas, this might be as a result of unhygienic practices during the processing of the product. This may range from methods of obtaining and quality of raw materials including sources of water, to the packaging, handling and distribution of the finished product to the final consumers. Considering the nutritional importance of groundnut cake and its suitability for incorporation into traditional and conventional products, it is hereby suggested that a small to medium scale production of groundnut cake be carried out under standard hygienic operation procedures. This will drastically reduce contamination and epidemics that may result in the consumption of improperly produced food and food products as well as popularize the nutritional benefits of the product.

\section{RECOMMENDATIONS}

Based on the results obtained above, it is recommended that:

- The National Agency for Food Drug Administration Control (NAFDAC) should pay attention to small scale businesses so as to ensure a wholesome food for the consumers.

- The producers of groundnut cake should use hygienic area, raw materials and equipment to reduce the high risk of microbial contamination

- The public should be enlightened, especially the producers, hawkers and consumers of this food product, on the resulting negative implication of unhygienic practices on human health.

\section{REFERENCES}

Abdalla, N. M., Haimour, W. O., Osman, A. A., Sarhan, M. A., and Musaa, H. A. (2012). Antibiotics Sensitivity Profile Towards $<\mathrm{i}>$ Staphylococcus hominis $</ \mathrm{i} \& \mathrm{gt}$; in Assir Region of Saudi Arabia. Journal of Scientific Research, 5(1), 171-183. https://doi.org/10.3329/jsr.v5i1.11704.

Atanda, O. and Akano, D. A. (1990). The present level of aflatoxin in Nigerian groundnut cake ('kulikuli'). Applied Microbiology, 10(4): 187-189.

Barrow, G.I. and Feltham, R.K.A. (1993). Cowan and Steel's Manual for the Identification of Medical Bacteria. Fifth edition. Cambridge University Press. Pp. 7-14, 219-238.

Beishir, L. (1991). Microbiology in Practice. A self-instructional laboratory course. $15^{\text {th }}$ edition.

Cheesbrough, M. (2006). District Laboratory Practice in Tropical Countries. 2nd Edn., Cambridge University Press, Cambridge, UK., ISBN-13: 9781139449298.

Clarence, S.Y., Obinna, C.N., and Shalom, N.C., (2009) Assessment of bacteriological quality of ready to eat food (meat pie) in Benin City metropolis, Nigeria. African Journal of Microbiology, Research 3: 390-395.

Doyle, E. M. (2007). FRI Briefings Microbial Food spoilage. Losses and Control Strategies. A Brief Review of the Literature. Food Research Institute, University of Winconsis - Madison.

Hassan, I. A., Emun, H. O.,Daramola, O. J. (2014). Microbial Profile of Puff Puff Sold Onthe Streets of Lagos State. International Journal of Advances in Pharmacy, Biology and Chemistry. Vol. 3(4), ISSN: $2277-4688$.

Hwang, W. S., Ryu, Y. J., Park, J. H., Park, E. S., Lee, E. G., et al. (2004). Evidence of a pluripotent human embryonic stem cell line derived from a cloned blastocyst. Science 303: 1669-1674.

MOI (2008). Ministry Of Information, Sokoto, Nigeria. Diary, Pp, 12.

Oko, J. O., Abriba, C., Audu, J. A., Kutman, N. A., and Okeh, Q. (2015). Bacteriological And Nutritional Analysis Of Groundnut Cake Sold In An Open Market In Samaru, Zaria-Kaduna State. International Journal of Scientific \& Technology research volume 4ISSN 2277-8616. 222-228.

Okonko, I.O., Adejoye, O.O., Ogun, A.A., Ogunjobi, A.A., Nkang, A.O., and Adebayo, B.C. (2009). Hazards Analysis Critical Control Points (HACCP) and Microbiology Qualities of Sea Foods as Affected by Handle's Hygiene in Ibadan and Lagos, Nigeria. African Journal Food Science, 3:035-050.

Okwu, G. I., Akpe, A.R., Amhanre, I. N. and Ogbon-Ogieva, E. (2017). Microorganism and Aflatoxin Content in 
Ready to Eat Groundnut Paste from some markets in Anambra and Edo state, Nigeria. Global Journal of Science Frontier Research: C Biological Science, 17(1):35-41.

Oluwafemi, F., and Simisaye, M.T. (2005). Extent of microbial contamination of sausage sold in two Nigeria cities. African Journal Biomedical Research, 9: 133-136.

Oyeleke S.B, and Manga, S.B. (2008). Essential Laboratory Practical in Microbiology (1 ${ }^{\text {sted.). }}$. To best Publisher, Niger State. Pp.36 - 58. and Pp 65-360.

SERC (2015). Sokoto Energy Research Center, Usmanu Danfodiyo University, Sokoto., Meteorological Data.

Sokari, T. (1991). Distribution of enterotoxigenic Staphylococcus aureus in ready-to-eat foods in eastern Nigeria. International Journal of Food Microbiology, 12(2-3):275- 279. 